\title{
Chemical properties during different development stages of fruit orchards in the mekong delta (Vietnam)
}

\author{
Pham van Quang ${ }^{1}$, Vo thi Guong ${ }^{2}$ \\ ${ }^{1}$ Department of Soil Science and Natural Resources, Faculty of Agriculture and Natural Resources, An Giang University, \\ Long Xuyên; Vietnam; Corresponding Author: phamvq@kth.se \\ ${ }^{2}$ Department of Soil Science and Natural Resources, Agriculture and Applied Biology College, Can Tho University, \\ Can Tho, Vietnam, Corresponding Author: vtguong@ctu.edu.vn
}

Received 1 July2011; revised 28 July 2011; accepted 6 August 2011.

\section{ABSTRACT}

This study to examine soil fertility status was conducted on 10 citrus plantations in Hau Giang province within the Vietnamese Mekong Delta, Vietnam. Fruit trees are mostly grown on the raised beds to avoid annual flood with alluvial soil type. Soil sampling was done in the dry season of 2010 at two soil depths, for each raised bed. Development ages of raised beds were represented by two groups, young age group ( $\leq 30$ years) and old age group ( $>30$ years). For chemical analysis, $\mathrm{pH}$, organic matter, CEC, total nitrogen, $\mathrm{NH}_{4}^{+}, \mathrm{NO}_{3}^{-}$and exchangeable $\mathrm{Ca}$, $\mathrm{Mg}$ and $\mathrm{K}$ were determined. The results showed that the pH (water) was strongly acid. The CEC was in average $19.2 \mathrm{cmol} \cdot \mathrm{kg}^{-1}$ in topsoil $(0-20$ $\mathrm{cm}$ depth) and $18.7 \mathrm{cmol} \cdot \mathrm{kg}^{-1}$ in subsoil (20 - 50 $\mathrm{cm}$ depth) for young age group. Similarly, the CEC was $16.7 \mathrm{cmol} \cdot \mathrm{kg}^{-1}$ in topsoil and 15.8 $\mathrm{cmol} \cdot \mathrm{kg}^{-1}$ in subsoil for old age group. Organic matter on young age group $\mathbf{( 7 . 3 8 \%}$ and $5.47 \%$ on average for topsoil and subsoil respectively) was significantly higher than that of old age group $(5.20 \%$ and $3.81 \%$ on average for topsoil and subsoil respectively). Total nitrogen was not significantly different between the sites for the age groups of raised as well as the soil layers. Ammonium-N levels were excessive, and $\mathrm{NO}_{3}^{-}-\mathrm{N}$ levels were high. Potassium and $\mathrm{Mg}^{2+}$ were significantly different between age groups of raised beds and the same pattern between soil layers, while $\mathrm{Ca}^{2+}$ did not vary significantly. Potassium and $\mathrm{Ca}^{2+}$ levels were moderate, $\mathrm{Mg}^{2+}$ was high and $P$ levels were very high. Soil fertility in the raised beds subjected to an adverse on plant growth and an imbalance in soil nutrients under low pH conditions. Loss of soil qual- ity was exhibited in reduced organic matter with the aging of raised beds.

Keywords: Citrus Orchards; Soil Properties; Alluvial Soil; Nutrient Balance; Soil Fertility; Mekong Delta; Vietnam

\section{INTRODUCTION}

There are seven major soil types in the Vietnamese Mekong Delta (MD); those are alluvial, acid sulphate, saline, saline acid sulphate, old alluvial, peat and mountainous $[1,2]$.

The MD is the main area of fruit production that covered approximately 285,300 ha by the year 2009 accounting for about $38 \%$ of the fruit tree area of Vietnam [3]. Most of the land used for fruit trees in the MD is lowland alluvial plain; therefore, raised beds are commonly constructed to avoid annual flooding. The raised beds are long raised soil trips that are higher than the original ground surface by piling up soil materials and excavating from adjacent lateral ditches. The ages of raised beds are also widely different which lots of them have lasted more than 30 years old. Soil layers on the raised beds are commonly arranged in reverse or the same order as natural soil. Thus, the soil is disturbed by the effect of human activities. With time, the soil may have changed under influence of physical and natural conditions as well as management practices. Soil degradation is considered as a subsequent limitation on plant growth. Major reasons of soil degradation are compaction, loss of organic matter, salinization, nutrient depletion and pollution $[4,5]$. Degradation of top soils may be easily resilient, whereas degradation of sub soils is much more difficult to restore and the degradation may even be permanent [6].

A record from this investigation was that the plant productivity has decreased as from the third or the fourth 
harvests due to young fruit drop and root rot. Many growers had to plant/sow new seeds into their soil. In some cases, they also had to introduce new soil below the stumps but this did not improve the situations either. A hypothesis can be raised related to soil degradation on fruit plantations that the old raised beds may expose more adverse restrictions to plant growth than the young ones. Additionally, there are many factors, which may cause the decrease in soil productivity, such as natural conditions and soil tillage. Although soil is a major source of nutrients that plants need to grow, the composition of fertilizer supplement is also necessary in return for the losses by plant uptake. Studies on soil chemical fertilizers, plants and their relationship were performed to recommend various formulations of NPK fertilizers by Phong et al. [7], Chau [8] and Hau [9], and these have helped fruit growers achieve balanced fertilization. However, the formulations of fertilizer application may be out of date if they are not periodically updated based on the nature of the soil in the field. Nutrient deficiencies and/or excesses have an adverse effect on plant growth and resulting plant yields. High concentrations of one nutritious substance in soil may cause imbalances or deficiencies of other elements [10].

A problem is that most of the land growing fruit plantation in the MD has acid soils with a low level of calcium $\left(\mathrm{Ca}^{2+}\right)$, magnesium $\left(\mathrm{Mg}^{2+}\right)$, and high levels of iron $\left(\mathrm{Fe}^{3+}\right)$ and free aluminum $\left(\mathrm{Al}^{3+}\right)$. Due to these character- istics, phosphate is fixed in less available forms [10]. The fixation of phosphate and potassium may be severe in some soils with a high clay content $[11,12]$. The acidity and salinity effects of fertilizers are important considerations in the selection and application of fertilizers [13]. In addition, the fertilization habits of growers in the MD often use a single rather than compound fertilizer, which stress the use of nitrogen while phosphorus, potassium, lime and micronutrients are less appropriately considered.

The objectives of this paper were to 1) assess the soil fertility by measuring $\mathrm{pH}$, organic matter, $\mathrm{CEC}$, total nitrogen, $\mathrm{NH}_{4}^{+}, \mathrm{NO}_{3}^{-}$and exchangeable $\mathrm{Ca}, \mathrm{Mg}$ and $\mathrm{K}$; 2) compare different ages of the raised beds to see if they differ in soil fertility; 3) identify possible nutrient imbalances.

\section{MATERIALS AND METHODS}

\subsection{Site Description}

This study was conducted on 10 selected citrus plantations in Hau Giang province, Mekong Delta, Vietnam with different ages (Figure 1). The plantations were divided into two main categories based on age: young age group: less than 30 years of age (normally 10 - 30 years), $\mathrm{n}=4$, and old age group: more than 30 years, $\mathrm{n}=6$ (Table 1). The soil was classified as alluvial soil $[14,15]$.

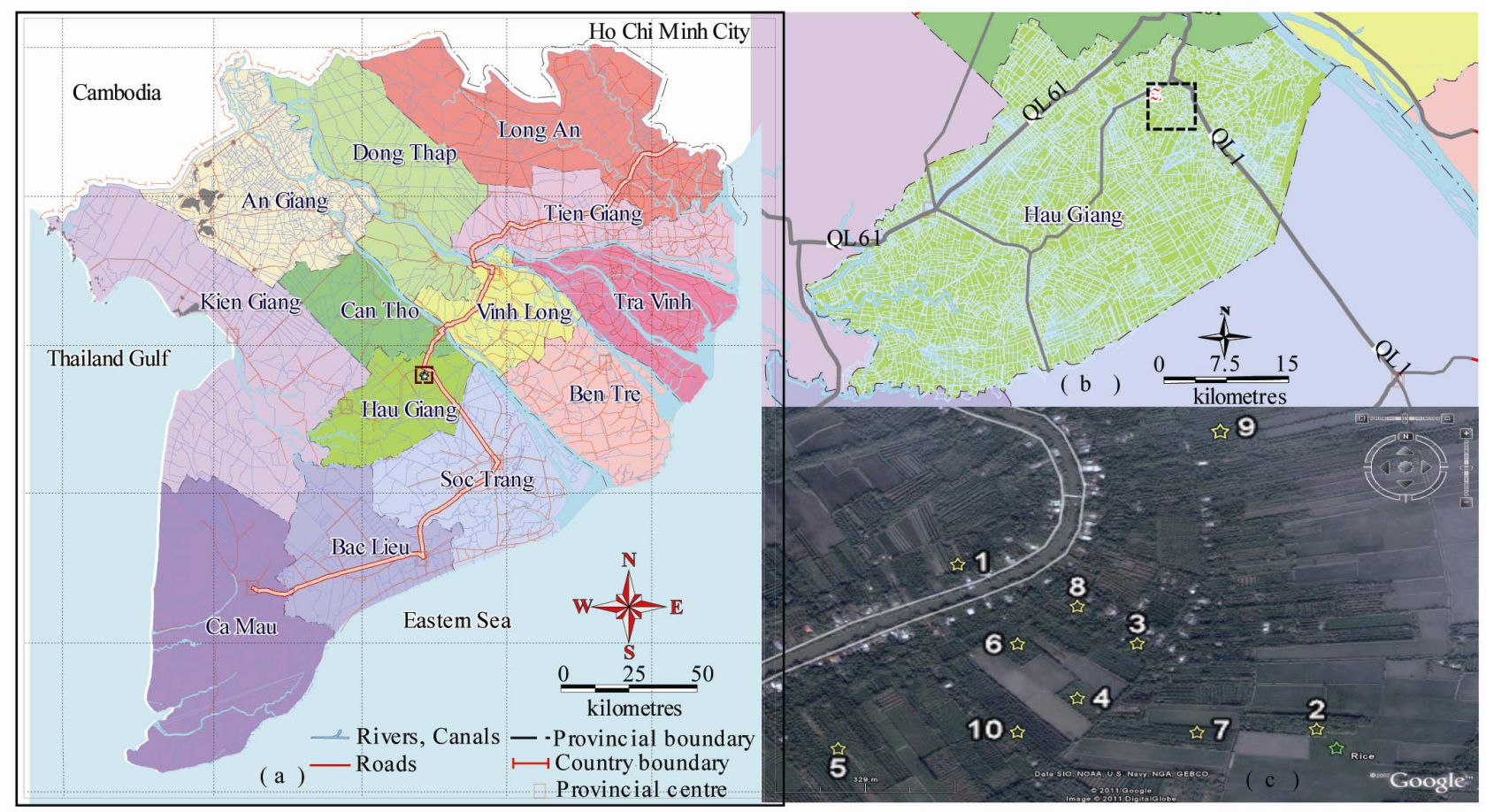

Figure 1. (a) Provincial Administrative Boundary Map of the Mekong Delta, (b) Map of Hau Giang Province, (c) Studied Sites Map-Extracted from Google Earth. 
Table 1. The ten study locations selected in Hau Giang province, Mekong Delta, Vietnam.

\begin{tabular}{cccc}
\hline Locations & Latitude & Longitude & ${\text { Construction } \text { year }^{\dagger}}^{\circ}$ \\
\hline 1 & $9^{\circ} 53^{\prime} 44.38^{\prime \prime}$ & $105^{\circ} 43^{\prime} 41.09^{\prime \prime}$ & 1995 \\
2 & $9^{\circ} 53^{\prime} 28^{\prime \prime}$ & $105^{\circ} 43^{\prime} 57.14^{\prime \prime}$ & 1993 \\
3 & $9^{\circ} 53^{\prime} 35.74^{\prime \prime}$ & $105^{\circ} 43^{\prime} 47.75^{\prime \prime}$ & 1991 \\
4 & $9^{\circ} 53^{\prime} 31.7^{\prime \prime}$ & $105^{\circ} 43^{\prime} 42.78^{\prime \prime}$ & 1980 \\
5 & $9^{\circ} 53^{\prime} 28^{\prime \prime}$ & $105^{\circ} 43^{\prime} 29.46^{\prime \prime}$ & 1979 \\
6 & $9^{\circ} 53^{\prime} 35.7^{\prime \prime}$ & $105^{\circ} 43^{\prime} 41.27^{\prime \prime}$ & 1978 \\
7 & $9^{\circ} 53^{\prime} 29.18^{\prime \prime}$ & $105^{\circ} 43^{\prime} 50.7^{\prime \prime}$ & 1978 \\
8 & $9^{\circ} 53^{\prime} 38.47^{\prime \prime}$ & $105^{\circ} 43^{\prime} 45.34^{\prime \prime}$ & 1977 \\
9 & $9^{\circ} 54^{\prime} 2.7^{\prime \prime}$ & $105^{\circ} 43^{\prime} 49.4^{\prime \prime}$ & Prior 1975 \\
10 & $9^{\circ} 53^{\prime} 29.22^{\prime \prime}$ & $105^{\circ} 43^{\prime} 41.16^{\prime \prime}$ & Prior 1975 \\
\hline
\end{tabular}

${ }^{\dagger}$ the year that raised beds were established

This study was conducted on 10 selected citrus plantations in Hau Giang province, Mekong Delta, Vietnam with different ages (Figure 1). The plantations were divided into two main categories based on age: young age group: less than 30 years of age (normally 10 - 30 years), $\mathrm{n}=4$, and old age group: more than 30 years, $\mathrm{n}=6$ (Table 1). The soil was classified as alluvial soil $[14,15]$. The climate is characterized by two distinct seasons, a dry season from January to April and a rainy season from May to December. The annual rainfall ranges from less than $1000 \mathrm{~mm}$ to over $1300 \mathrm{~mm}$, however most of the rain $(90 \%)$ falls during the rainy season. The mean temperature ranges from $23-25^{\circ} \mathrm{C}$ during the coldest months to $32-33^{\circ} \mathrm{C}$ during the warmest months. The humidity is highest in September (91\%), and the lowest in the dry season $(79 \%-82 \%)$.

The data was collected in the beginning of the dry season, January 2010. Soil samples were taken from each of the raised beds for chemical analyses at $0-20$ $\mathrm{cm}$ and $20-50 \mathrm{~cm}$ depth with 4 replications at each site and about $4 \mathrm{~kg}$ for each layer.

\subsection{Soil Analysis}

Soil samples were air-dried, homogenized and sieved through a $2 \mathrm{~mm}$ mesh screen to determine soil chemical properties including $\mathrm{pH}$, organic matter, $\mathrm{CEC}$, total nitrogen, $\mathrm{NH}_{4}^{+}, \mathrm{NO}_{3}^{-}$and exchangeable $\mathrm{Ca}^{2+}, \mathrm{Mg}^{2+}$ and $\mathrm{K}^{+}$.

$\mathrm{pH}$ was measured in water at 1:2.5 soil:water ratio. Organic carbon was determined by the Walkley and Black method [16] with the correction factor of 1.33 (recovery of $75 \%$ ). The percent of soil organic matter was calculated by multiplying the percent organic carbon by a factor of 1.724 , following the standard practice that organic matter is composed of $58 \%$ carbon [17]. Cation Exchange Capacity was determined by the barium chloride method. Total nitrogen was analyzed using the Macro Kjeldahl method, where the soil sample is digested by sulphuric-salicylic acid with a catalyst, and titrated by volumetry with $0.1 \mathrm{~N} \mathrm{H}_{2} \mathrm{SO}_{4}$. The available phosphorous of the soil was extracted according to Bray2 method and the concentration was then determined colorimetrically [18]. The exchangeable cations $\mathrm{Ca}^{2+}$, $\mathrm{Mg}^{2+}, \mathrm{K}^{+}$and $\mathrm{Na}^{+}$were extracted with $\mathrm{BaCl}_{2}$ and analysed by flame atomic absorption spectrometer. Inorganic $\mathrm{N}\left(\mathrm{NO}_{3}^{-}\right.$and $\left.\mathrm{NH}_{4}^{+}\right)$was extracted with $2 \mathrm{M} \mathrm{KCl}$ followed by determination according to standard colorimetric pro- cedures.

Statistical analyses were performed using SPSS software. One-way ANOVA with four treatments were performed using a 5\% significance level. The treatments included:

- Topsoil: 0 - $20 \mathrm{~cm}$ depth and young age group of raised beds: 10 - 30 years old;

- Subsoil: $20-50 \mathrm{~cm}$ depth and young age group of raised beds: 10 - 30 years old;

- Topsoil: $0-20 \mathrm{~cm}$ depth and old age group of raised beds: $>30$ years old;

- Subsoil: 20 - $50 \mathrm{~cm}$ depth and old age group of raised beds: $>30$ years old.

\section{RESULTS AND DISCUSSIONS}

\subsection{Soil pH (Water 1:2.5)}

The results of soil $\mathrm{pH}$ showed that the $\mathrm{pH}$ was higher in the young raised beds compared to the old raised beds and the same pattern for soil layers (Tables 2 and 3). However, there were no significant differences between the two age groups of raised beds as well as between soil layers for the young age group, while the $\mathrm{pH}$ was significantly different between topsoil and subsoil for the old age group.

The low pH may be caused by some factors such as plant uptake of base cations, nutrition leaching, accumulation of hydrogen ion $\left(\mathrm{H}^{+}\right)$and unbalanced fertilizer

Table 2. Soil pH (water), cation exchange capacity (CEC) and organic matter of young-group and old-group of raised beds for $0-20 \mathrm{~cm}$ depth.

\begin{tabular}{ccccc}
\hline \multirow{2}{*}{ Group } & Site & $\begin{array}{c}\text { pH-water } \\
(1: 2.5)\end{array}$ & $\begin{array}{c}\text { CEC } \\
\left(\mathrm{cmol}^{*} \mathrm{~kg}^{-1}\right)\end{array}$ & $\begin{array}{c}\text { Organic matter } \\
(\%)\end{array}$ \\
& 1 & 4.71 & 22.07 & 12.19 \\
Young & 2 & 4.44 & 20.02 & 5.18 \\
& 3 & 4.35 & 19.23 & 6.61 \\
& 4 & 4.24 & 15.59 & 5.54 \\
& Means & 4.43 & $19.23^{*}$ & $7.38^{*}$ \\
& 5 & 4.43 & 17.37 & 4.45 \\
& 6 & 4.36 & 14.87 & 4.57 \\
& 7 & 4.35 & 18.73 & 4.46 \\
& 8 & 4.49 & 16.78 & 4.36 \\
& 9 & 4.21 & 16.17 & 4.53 \\
& 10 & 3.93 & 16.35 & 8.81 \\
& Means & $4.29^{*}$ & $16.71^{*}$ & $5.20^{*}$ \\
\hline
\end{tabular}

${ }^{*}$ The mean difference is significant at the 0.05 level between age group; ${ }^{\dagger}$ The mean difference is significant at the 0.05 level between soil layers for young age group; ${ }^{\dagger}$ The mean difference is significant at the 0.05 between soil layers for old age group. 
Table 3. Soil pH (water), Cation Exchange Capacity (CEC) and Organic Matter of Young-group and Old-group of Raised Beds for $20-50 \mathrm{~cm}$ Depth.

\begin{tabular}{ccccc}
\hline Group & Site & $\begin{array}{c}\mathrm{pH} \text {-water } \\
(1: 2.5)\end{array}$ & $\begin{array}{c}\text { CEC } \\
\left(\mathrm{cmol} \cdot \mathrm{kg}^{-1}\right)\end{array}$ & $\begin{array}{c}\text { Organic matter } \\
(\%)\end{array}$ \\
\hline \multirow{6}{*}{ Young } & 1 & 5.11 & 21.60 & 9.59 \\
& 2 & 4.89 & 20.40 & 3.55 \\
& 4 & 4.52 & 17.70 & 4.34 \\
& Means & 4.13 & 15.15 & 4.38 \\
& 5 & 4.67 & $18.71^{*}$ & $5.47^{*}$ \\
& 6 & 4.80 & 16.27 & 3.41 \\
& 7 & 4.55 & 14.18 & 3.25 \\
& 8 & 4.70 & 18.07 & 3.11 \\
& 9 & 4.27 & 15.71 & 2.99 \\
& 10 & 4.23 & 14.93 & 3.65 \\
& Means & $4.52^{*}$ & 15.74 & 6.47 \\
\hline
\end{tabular}

*The mean difference is significant at the 0.05 level between age group; ${ }^{\dagger}$ The mean difference is significant at the 0.05 level between soil layers for young age group; ${ }^{+}$The mean difference is significant at the 0.05 between soil layers for old age group.

supply. The range of soil $\mathrm{pH}$ for citrus growth is between 5.5 and 8.0, however, the best soil $\mathrm{pH}$ for citrus plantation is between 5.5 and 6.5 [19]. When the $\mathrm{pH}$ falls below 5.0, it can lead to aluminum toxicity and manganese toxicity in root zone. A low $\mathrm{pH}$ condition can also cause a deficiency of nutrients such as calcium, magnesium, phosphorus, and molybdenum [20]. Decreasing soil $\mathrm{pH}$ can also cause decline of the mineralization and nitrification $[21,22]$. Soil $\mathrm{pH}$ at all sites was rated as strongly acid [23], therefore, deficiency of major plant nutrients such as calcium, magnesium, nitrogen and phosphorus may occur. In the low range of soil $\mathrm{pH}$, the adsorbed $\mathrm{H}^{+}$ and $\mathrm{Al}^{3+}$ may predominate the cation exchange capacity.

\subsection{Cation Exchange Capacity (CEC)}

Cation exchange capacity (CEC) in the two groups of raised beds is shown in Tables 2 and $\mathbf{3}$ for topsoil and subsoil. The CEC of the old age group was significantly lower than that of the young age group, while there were no significant differences between topsoil and subsoil for both age groups.

Cation exchange capacity of a soil refers to the amount of positively charge ions that a soil can retain. When a soil becomes more acidic the base cations are replaced by $\mathrm{H}^{+}, \mathrm{Al}^{3+}$ and $\mathrm{Mn}^{2+}$ and this also produce higher CEC values [24]. The higher the $\mathrm{CEC}$, the more amounts of nutrients the soil is able to supply [24]. The CEC of the soil depends on the kind of clay, organic matter content, $\mathrm{pH}$ and soil formation. The CEC of all study sites was ranked as moderate [25], this may indicate the restriction of soil nutrients to plants. However, the aging of raised beds is also an important factor. Because decreases in soil $\mathrm{pH}$ and organic matter with the aging of raised beds may contribute to the decrease in negatively charge components and this may then reduce nutrient holding capacity of the soil.

\subsection{Organic matter}

Organic matter content for the young age group (7.4\% and $5.5 \%$ on average for topsoil and subsoil respectively) was significantly higher than that of the old age group (5.2\% and $3.8 \%$ on average for topsoil and subsoil respectively). The topsoil contained more organic matter than the subsoil in both age groups (Tables 2 and 3). The results showed that the amount of organic matter was remarkably high for site 1 and site 10 compared to the others. For site 1, the raised bed was built up on low landform and there had existed a humus layer in the soil profile with many decayed and semi-decayed materials from 0.5 to $2 \mathrm{~m}$ depth. Because of the raised bed construction, part of the humus layer below was brought to the surface; this was probably a reason for the higher organic matter content of site 1 . For site 10, rather good management practices of the owner's raised bed garden were executed by returning the residual materials of plant or vegetation into the soil.

Organic matter play a crucial role in soil fertility, buffering capacity, water holding capacity and stabilization of soil structure $[10,26]$.

\subsection{Exchangeable Cations}

Tables 4 and 5 show the mean values for exchangeable cations $\left(\mathrm{K}^{+}, \mathrm{Na}^{+}, \mathrm{Mg}^{2+}\right.$ and $\left.\mathrm{Ca}^{2+}\right)$ between different ages of raised beds and between soil layers.

The results showed that the concentrations of $\mathrm{K}^{+}$and $\mathrm{Mg}^{2+}$ were significantly lower for the old age group, while it was not significantly different for $\mathrm{Ca}^{2+}$ (Tables 4 and 5). The base cations concentrations were higher in

Table 4. Exchangeable cations of young-group and old-group of raised beds for $0-20 \mathrm{~cm}$ depth.

\begin{tabular}{|c|c|c|c|c|}
\hline \multirow{2}{*}{ Group } & \multirow{2}{*}{ Site } & $\mathrm{K}^{+}$ & $\mathrm{Mg}^{2+}$ & $\mathrm{Ca}^{2+}$ \\
\hline & & \multicolumn{3}{|c|}{$\left(\mathrm{cmol} \cdot \mathrm{kg}^{-1}\right)$} \\
\hline \multirow{4}{*}{ Young } & 1 & 0.46 & 3.45 & 9.85 \\
\hline & 2 & 0.53 & 5.02 & 6.99 \\
\hline & 3 & 0.81 & 3.20 & 7.72 \\
\hline & 4 & 0.26 & 2.52 & 5.24 \\
\hline \multirow{10}{*}{ Old } & Means & $0.52^{* \dagger}$ & $3.55^{*}$ & 7.45 \\
\hline & $\% \mathrm{CEC}$ & 2.65 & 18.38 & 38.33 \\
\hline & 5 & 0.24 & 2.94 & 8.00 \\
\hline & 6 & 0.27 & 2.75 & 6.42 \\
\hline & 7 & 0.33 & 2.62 & 6.90 \\
\hline & 8 & 0.40 & 3.34 & 6.76 \\
\hline & 9 & 0.33 & 1.45 & 4.58 \\
\hline & 10 & 0.46 & 2.81 & 7.46 \\
\hline & Means & $0.34^{*}$ & $2.65^{*}$ & 6.69 \\
\hline & $\% \mathrm{CEC}$ & 2.03 & 15.91 & 40.05 \\
\hline
\end{tabular}

*The mean difference is significant at the 0.05 level between age group; ${ }^{\dagger}$ The mean difference is significant at the 0.05 level between soil layers for young age group; ${ }^{*}$ The mean difference is significant at the 0.05 between soil layers for old age group. 
Table 5. Exchangeable cations of young-group and old-group of raised beds for $20-50 \mathrm{~cm}$ depth.

\begin{tabular}{ccccc}
\hline Group & Site & $\mathrm{K}^{+}$ & $\mathrm{Mg}^{2+}$ & $\mathrm{Ca}^{2+}$ \\
\hline \multirow{6}{*}{ Young } & 1 & 0.54 & 3.25 & 9.69 \\
& 2 & 0.33 & 6.43 & 5.71 \\
& 3 & 0.58 & 2.66 & 7.08 \\
& 4 & 0.23 & 2.08 & 5.06 \\
& Means & $0.42^{* \dagger}$ & $3.60^{*}$ & 6.89 \\
& \% CEC & 2.23 & 18.83 & 36.56 \\
& 5 & 0.25 & 2.52 & 6.96 \\
Old & 6 & 0.22 & 2.29 & 5.99 \\
& 7 & 0.29 & 2.93 & 6.09 \\
& 8 & 0.26 & 3.17 & 6.23 \\
& 9 & 0.22 & 1.69 & 4.41 \\
& 10 & 0.34 & 3.10 & 6.63 \\
& Means & $0.26^{* \ddagger}$ & $2.62^{*}$ & 6.05 \\
& \% CEC & 1.66 & 16.51 & 38.34 \\
\hline
\end{tabular}

*The mean difference is significant at the 0.05 level between age group; ${ }^{\dagger}$ The mean difference is significant at the 0.05 level between soil layers for young age group; ${ }^{\dagger}$ The mean difference is significant at the 0.05 between soil layers for old age group.

topsoil compared to subsoil for within the same age group as well as for between age groups. The amount of $\mathrm{K}^{+}$and $\mathrm{Ca}^{2+}$ was ranked as a moderate level, while $\mathrm{Mg}^{2+}$ was ranked as a high level [27]. The percent base saturation of calcium, magnesium, sodium, and potassium in the soil may indicate that there was a deficiency and/or excess in the balance of available nutrients to plants. The following proportions of the various cations suggested by Abbott [28] for optimum crop performance are usually within the following ranges: potassium $1 \%-5 \%$, magnesium $10 \%-15 \%$, calcium $65 \%-80 \%$ and sodium $<2.5 \%$. Based on most efficient range suggested above, for this study, only exchangeable potassium/CEC (\%) was in a good range, while exchangeable magnesium /CEC (\%) was slightly higher and exchangeable calcium/CEC (\%) was rather lower (Tables 4 and 5). This indicated that there existed an imbalance of cations in both young and old age group of raised beds.

\subsection{Total Nitrogen, Ammonium and Exchangeable Nitrate}

Total nitrogen varied in the range from $0.14 \%-0.27 \%$ in young age group and $0.15 \%-0.22 \%$ in old age group for topsoil (Table 6), from $0.10 \%-0.13 \%$ in young age group and $0.10 \%-0.16 \%$ in old age group for subsoil (Table 7). Total nitrogen was not significantly different between the two age groups, while it was significantly higher in topsoil compared to subsoil for both age groups (Tables 6 and 7).

Ammonium concentrations were $21.0-32.8 \mathrm{mg} \cdot \mathrm{kg}^{-1}$ in young age group and $14.3-37.4 \mathrm{mg} \cdot \mathrm{kg}^{-1}$ in old age group for topsoil (Table 6). For subsoil, the values are $15.6-33.6 \mathrm{mg} \cdot \mathrm{kg}^{-1}$ in young age group and $20.8-32.8$ $\mathrm{mg} \cdot \mathrm{kg}^{-1}$ in old age group (Table 7).

Exchangeable nitrate changed between 27.2 and 64.8
Table 6. Total Nitrogen, Exchangeable Ammonium, Exchangeable Nitrate and available P of Young-group and Oldgroup of Raised Beds for 0 - $20 \mathrm{~cm}$ Depth.

\begin{tabular}{cccccc}
\hline Group & Site & $\mathrm{N}_{\text {total }}$ & $\mathrm{NH}_{4}^{+}$ & $\mathrm{NO}_{3}{ }^{-}$ & $\mathrm{P}$ \\
\hline \multirow{6}{*}{ Young } & & $\mathbf{( \% )}$ & & $\left(\mathrm{mg} \cdot \mathrm{kg}^{-1}\right)$ & \\
& 1 & 0.27 & 32.10 & 41.85 & 26.90 \\
& 2 & 0.14 & 21.02 & 27.18 & 23.01 \\
& 3 & 0.15 & 32.79 & 64.83 & 37.64 \\
& 4 & 0.16 & 24.39 & 63.40 & 24.41 \\
& Means & $0.18^{\dagger}$ & 27.57 & $49.31^{* \dagger}$ & 27.99 \\
& 5 & 0.22 & 14.31 & 44.62 & 31.87 \\
& 6 & 0.15 & 25.32 & 26.38 & 41.94 \\
& 7 & 0.19 & 18.00 & 24.25 & 43.21 \\
& 8 & 0.15 & 37.44 & 40.03 & 16.60 \\
& 9 & 0.19 & 28.21 & 44.81 & 41.97 \\
& 10 & 0.22 & 34.67 & 33.87 & 19.78 \\
& Means & $0.19^{\ddagger}$ & 26.32 & $35.66^{*}$ & $32.56^{\ddagger}$ \\
\hline
\end{tabular}

* The mean difference is significant at the 0.05 level between age group ${ }^{\dagger}$ The mean difference is significant at the 0.05 level between soil layers for young age group; ${ }^{\ddagger}$ The mean difference is significant at the 0.05 between soil layers for old age group.

Table 7. Total Nitrogen, Exchangeable Ammonium, Exchangeable Nitrate and available P of Young-group and Oldgroup of Raised Beds for 20 - $50 \mathrm{~cm}$ Depth.

\begin{tabular}{cccccc}
\hline Group & Site & $\mathrm{N}_{\text {total }}$ & $\mathrm{NH}_{4}{ }^{+}$ & $\mathrm{NO}_{3}^{-}$ & $\mathrm{P}$ \\
\hline \multirow{6}{*}{ Young } & & $(\%)$ & & $\left(\mathrm{mg} \cdot \mathrm{kg}^{-1}\right)$ & \\
& 1 & 0.20 & 33.25 & 14.63 & 28.61 \\
& 2 & 0.10 & 15.65 & 15.06 & 25.75 \\
& 3 & 0.10 & 31.76 & 17.99 & 21.71 \\
& Means & 0.13 & 18.08 & 17.12 & 30.01 \\
& 5 & $0.13^{\dagger}$ & 24.68 & $16.20^{\dagger}$ & 26.52 \\
& 6 & 0.16 & 32.84 & 21.29 & 18.25 \\
& 7 & 0.11 & 20.78 & 13.37 & 31.68 \\
& 8 & 0.13 & 25.41 & 19.39 & 37.22 \\
& 9 & 0.10 & 32.61 & 19.47 & 24.23 \\
& 10 & 0.16 & 22.55 & 9.37 & 26.40 \\
& Means & 0.16 & 28.16 & 13.25 & 14.64 \\
& $0.13^{\ddagger}$ & 22.18 & $16.02^{\ddagger}$ & $25.40^{\ddagger}$ \\
\hline
\end{tabular}

*The mean difference is significant at the 0.05 level between age group; ${ }^{\dagger}$ The mean difference is significant at the 0.05 level between soil layers for young age group; ${ }^{\ddagger}$ The mean difference is significant at the 0.05 between soil layers for old age group.

$\mathrm{mg} \cdot \mathrm{kg}^{-1}$ in young age group, between $24.2-44.8 \mathrm{mg} \cdot \mathrm{kg}^{-1}$ in old age group for topsoil (Table 6). The values for subsoil changed between $14.6-18.0 \mathrm{mg} \cdot \mathrm{kg}^{-1}$ in young age group, between $9.4-21.3 \mathrm{mg} \cdot \mathrm{kg}^{-1}$ in old age group (Table 7). The $\mathrm{NO}_{3}^{-}$amount in young age group was significantly higher than that in old age group for topsoil, however, for subsoil, there was no significant difference between the age groups. Furthermore, there was a significant difference on $\mathrm{NO}_{3}{ }^{-}$between topsoil and subsoil for the young age group as well as for the old age group.

Rating according to Bruce and Rayment [23], the soils of this study were moderate in total nitrogen, high in organic carbon and in $\mathrm{C}: \mathrm{N}$ ratio. However, the $\mathrm{C}: \mathrm{N}$ ratio was lower in old age group than in young age group. This indicated that the decomposition process was faster in old age group; and therefore, there is usually a release 
of mineral $\mathrm{N}$ early in the decomposition process. For this study, soil $\mathrm{NH}_{4}{ }^{+}-\mathrm{N}$ levels were above $10 \mathrm{mg} \cdot \mathrm{kg}^{-1}$ at all of the observed sites, and $\mathrm{NO}_{3}{ }^{-} \mathrm{N}$ levels were excessive and high for $0-20 \mathrm{~cm}$ and $20-50 \mathrm{~cm}$ depth respectively as evaluated following Marx et al. [27] (Tables 6 and 7). This exhibited that the soil contained too much fertilizer residue.

\subsection{Available Phosphorous}

Phosphorous concentration was $23.0-37.6 \mathrm{mg} \cdot \mathrm{kg}^{-1}$ in young age group and $19.8-43.2 \mathrm{mg} \cdot \mathrm{kg}^{-1}$ in old age group for topsoil (Table 6). For subsoil, the range is 21.7 - $30.0 \mathrm{mg} \cdot \mathrm{kg}^{-1}$ in young age group and 14.6 - 37.2 $\mathrm{mg} \cdot \mathrm{kg}^{-1}$ in old age group (Table 7). There was no significant difference between the two age groups, but phosphorous was significantly higher in the top soil compared to the subsoil for the old age group. The results (Tables 6 and 7) showed that phosphorous (on average values) was ranked as very high based on Abbott [28].

\section{CONCLUSIONS}

The insufficient soil fertility in the raised beds has had an adverse effect on plant growth. The results indicated that there existed an imbalance in soil nutrients under low $\mathrm{pH}$ conditions; therefore, this may lead to plant production problems. Loss of soil quality was also exhibited in reduced organic matter with the aging of raised beds. Excess nitrogen and phosphorous in soil may leach out to streams, rivers and groundwater.

In managing these fruit plantations on the raised beds in the Mekong Delta, fruit growers should pay attention on the following issues.

- Raise the soil pH;

- Balance fertilizer application;

- Manage the soil moisture;

- Improve the soil's physical qualities.

\section{ACKNOWLEDGEMENTS}

We gratefully show appreciation to Mr. Ngo Xuan Hien, Agronomy Bureau, Chau Thanh District, Hau Giang Province, Vietnam for help and encouragement throughout the field works. We thank all raised beds' owners for their kindly support of study locations. We also thank Huynh Ngoc Duc and Pham Xuan Phu for the assistance during data collection; Ly Ngoc Thanh Xuan and analysis laboratory staff, Faculty of Agriculture and Natural Resources, An Giang University, Vietnam for their help with soil chemical testing. We are grateful to Per-Erik Jansson and Carin Sjöstedt for providing very helpful comments to improve this manuscript.

\section{REFERENCES}

[1] Khoa, L.V. (2000) Soil degradation and land conservation with special reference to soil resources in the Mekong delta, Vietnam. Lecture Note (Vietnamese), Can Tho University.

[2] Ve, N.B. and Anh, V.T. (1990) Soil map of the mekong delta 1:250,000 scale based on USDA system. University of Can Tho and 60B Project.

[3] General Statistics Office (2010) Statistical yearbook 2009. Statistical Publishing House, Hanoi.

[4] Syers, J.K. (1997) Managing soils for long-term productivity. Biological Sciences, 352, 1011-1021. doi:10.1098/rstb.1997.0079

[5] Oldeman, L.R. (1994) The global extent of soil degradation. Soil Resilience and Sustainable Land Use, CAB International, Wallingford, 99-118.

[6] Dexter, A. and Zoebisch, M. (2005) Degradation: Critical limits of soil properties and irreversible degradation, In: Chesworth, W., Ed., Encyclopedia of Soil Science, $2^{\text {nd }}$ Edition, CRC Press, Boca Raton.

[7] Phong, L.T., Hoang, V.T. and Minh, D. (1996) Citrus. Agriculture Publisher, Ho Chi Minh. (In Vietnamese).

[8] Chau, N.M. (1997) Using fertilizer for some fruit-trees. Agriculture, Land Resources and Fertilizer Use in Vietnam. Youth Publisher, Ho Chi Minh City. (In Vietnamese).

[9] Hau, V.C. (1999) Fruit cultivation in vietnam. Agriculture Publisher, Ho Chi Minh City. (In Vietnamese).

[10] Jones, J.B. (2003) Agronomic handbook: Management of crops, soils, and their fertility, CRC Press, Boca Raton.

[11] Siem, N.T., How to use NPK fertilizers for a sustainable intensive farming structure. Agriculture, Land Resources and Fertilizer Use in Vietnam. Youth Publisher, Ho Chi Minh City. (In Vietnamese).

[12] Hoa, N.M. (1997) Soil potassium dynamics under intensive rice cropping: A case study in the Mekong Delta, Vietnam.

[13] Foth, H.D. (1990) Fundamentals of soil science. Wiley, New York.

[14] Soil Survey Staff (1996) Key to soil taxonomy. Handbook, $6^{\text {th }}$ Eddition, USDA, USA.

[15] Soil Science Department (1985-1996) Reports of soil survey and mapping in the Mekong delta, scales 1/25,000 and 1/100,000. College of Agriculture, Can Tho University, Vietnam.

[16] Walkley, A. and Black, I.A. (1934) An examination of the degtjareff method for determining soil organic matter, and a proposed modification of the chromic acid titration method. Soil Science, 37, 29-38. doi:10.1097/00010694-193401000-00003

[17] Brady, N.C. (1985) The nature and properties of soils. $8^{\text {th }}$ Edition, Eurasia Publishing House, New Delhi.

[18] Bray, R.H. and Kurtz, L.T. (1945) Determination of total, organic, and available forms of phosphorus in soils. Soil Science, 59, 39-46. doi:10.1097/00010694-194501000-00006

[19] Calabrese, F. (2002) Soil and cultural practices. In: Dugo, G. and di Giacomo, A., Ed., Citrus: The Genus Citrus. 
Medicinal and Aromatic Plants-Industrial Profiles, Taylor and Francis, London and New York, 1027-4502.

[20] Tan, K.H. (2005) Soil sampling, preparation, and analysis. Books in soils, plants, and the environment. Taylor \& Francis, Boca Raton.

[21] Fu, M.H., Xu, X.C. and Tabatabai, M.A. (1987) Effect of $\mathrm{pH}$ on nitrogen mineralization in crop-residue-treated soils. Biology and Fertility of Soils, 5, 115-119. doi:10.1007/BF00257645

[22] Slattery, J.F., Slattery, W.J. and Carmody, B.C. (1999) Influence of soil chemical characteristics on medic rhizobia in the alkaline soils of south eastern Australia. In: Martinez, E. and Hernandez, G., Eds., Highlights of Nitrogen Fixation Research, Kluwer Academic/Plenum Publishers, New York, 243-249.

[23] Bruce, R.C. and Rayment, G.E. (1982) Analytical meth- ods and interpretations used by the Agricultural Chemistry Branch for soil and land use surveys. Queensland Department of Primary Industries Bulletin No. QB82004, Brisbane.

[24] McKenzie, N. (2004) Australian soils and landscapes: An illustrated compendium. CSIRO, Collingwood.

[25] Metson, A.J. (1961) Methods of chemical analysis for soil survey samples, soil bureau bulletin 12. Department of Scientific and Industrial Research, New Zealand.

[26] Lal, R. and Shukla, M.K. (2004) Principles of soil physics. Marcel Dekker, New York.

[27] Marx, E., et al. (1996) Soil test interpretation guide. Oregon State University Extension Service.

[28] Abbott, T.S. (1985) Soil Testing service-methods and interpretation. NSW Department of Agriculture, Sydney. 